\title{
Trace elements and nuclear abnormalities in fish species of two brazilianestuarine regions - an attempt to increase the matrix for environmental monitoring
}

\begin{abstract}
Trace elements $\mathrm{As}, \mathrm{Co}, \mathrm{Fe}, \mathrm{Hg}, \mathrm{Se}, \mathrm{Zn}$ and $\mathrm{Cr}$ were determined in muscle tissue, gills and liver and nuclear abnormalities in erythrocytes (NAEs) were observed in 7 fish species (Chaetodipterusfaber, Paralanchurusbrasiliensis, Micropogoniasfurnieri, Achiruslineatus, Genyatremusluteus, Menticirrhus Americanos and Micropogoniasfurnieri), from two estuarine regions subject to different levels of anthropogenic impact (preserved and polluted) to provide information on contamination levels. The bioaccumulation in $C$. faber suggested that it should be proposed as a bioindicator of pollution in estuaries. The hydrological data: temperature, salinity and dissolved oxygen characterized the estuarine waters. A paradoxical result relating to $\mathrm{As}, \mathrm{Co}, \mathrm{Fe}$ and $\mathrm{Zn}$ concentrations was that, in general, these were higher in the fish species of the Cananeia estuary (a preserved area), while Hg concentrations and NAEs were higher in the species of the Santos-São Vicente estuary (SSV) (the polluted area). The bioaccumulation in tissue-organs decreased in the following order: liver $>$ gill $>$ muscle, with the exception of $\mathrm{Hg}$ that was liver $>$ muscle with no detection in gills. Concerning the genotoxic effects, C. faber showed a more significant NAE, besides clastogenic effects, demonstrated by the greater frequency of micronuclei. Differences found between the fish species could be related to their feeding habits and to salinity. This is a contribution to making fishery efforts more profitable and enhancing the bioindicator bank.
\end{abstract}

Keywords: Bioindicator, Genotoxic effect, Trace metals, Micronuclei, Bioaccumulation, Coastal systems
Volume 6 Issue 2 - 2017

\author{
Azevedo JS, ${ }^{2}$ Oliveira AL,' F varo DIT, ${ }^{3}$ Braga \\ ES' \\ 'Instituto Oceanográfico, Universidade de São Paulo, Brazil \\ 2Instituto de Ciências Ambientais, Química e Farmacêuticas, \\ Universidade Federal de São Paulo, Brazil \\ ${ }^{3}$ Laboratório de Ativação Neutrônica, Instituto de Pesquisas \\ Energéticas e Nucleares, Brazil
}

\begin{abstract}
Correspondence: Braga ES, Instituto Oceanográfico, Universidade de São Paulo, Department of Environmental Sciences, Brazil, Email Juliana_azevedo@msn.com
\end{abstract}

Received: August 01, 2017| Published: August 04, 2017

\section{Introduction}

Coastal areas are constantly subject to the input of various chemical compounds that, in association with the abiotic variables in the wateras for instance salinity, organic matter, $\mathrm{pH}$, dissolved oxygen and temperature, can change the solubility and the accumulation profile in the matrices such as sediment and organisms. Thus, in monitoring programs of coastal ecosystems such as estuaries, the integrated study of the identification of chemical compounds and their quantification - as well as of their possible chronic effect on the biota - is especially interesting.

Estuaries are defined as partially enclosed coastal bodies of water which are either permanently or periodically open to the sea and within which there is a measurable variation of salinity due to the mixture of seawater with the freshwater derived from land drainage. ${ }^{1}$ These environments provide several ecosystem services such as the supply of potable water, fisheries, climate regulation, sheltered access to coastal water, coastal protection, water purification and waste treatment. ${ }^{2}$ On the other hand, they have been intensively occupied by human activities, suffering thus by the deleterious dilution and disposal of chemical waste worldwide., ${ }^{3,4}$ This contamination is intensified by freshwater input, increasing urbanization and the discharge of domestic and industrial effluents, the burning of fossil fuels, mining, groundwater use, surface runoff and soil erosion, and the mobilization of historical contaminated sediment). ${ }^{5}$ In addition, some of these contaminants persist in the environment, and all metals (essential and non-essential) are potentially bioavailable and noxious to aquatic biota, in some cases highly toxic even at low levels. ${ }^{3,6}$
Cananeia estuary is an aquatic ecosystem located in the southern coastal region of São Paulostate (Brazil), subject to minimal anthropogenic influence it is part of an enormous estuarinelagoon complex. The southern part of it receives greater oceanic influence, presenting, therefore, evident natural estuarine conditions. Furthermore, it presents great biodiversity, being considered a world biota reserve by UNESCO. ${ }^{7}$ On the other hand, the northern region of this estuary is characterized by the freshwater inflow from an artificial channel that links the Ribeira de Iguape River directly to the estuary, representing an important input of different materials of continental and anthropogenic origin into the general system. This influence is not clearly perceived in the southern area-the Cananeia estuary properly so called. The Santos/São Vicente estuarine system (SSV), located in the central coastal region of São Paulo state, Brazil, is subject to constant biomonitoring since the inner area of this region, where Cubatão city is located, was in the 80 s considered one of the most polluted places in the world. This region congregates about 1,100 factories that operate in different domains such as metallurgy, steel milling and the production of inputs for the chemical industry, as well as sheltering the largest port in Latin America. Therefore, in this region there is a great industrial source of pollution beyond the domestic and port discharge of materials into the aquatic system.

In aquatic systems, the bioavailability of pollutants results in their bio-concentration in organisms and fish species some of which present advantages in terms of environmental monitoring due to the ease of the capture of multiple species associated with their positions in the food chain. The input of contaminants into fish organisms can take place from sediments, suspended particulate material, the water 
column and food sources and their main paths of entry will depend on the particular dietary and ecological lifestyle of the fish. ${ }^{8}$ The gravity of the effect of pollutants on fish organisms is associated with the toxicity of each of the polluting substances and is related to the characteristic environmental and metabolic processes of the organisms concerned. As a result, the fish species maintain specific relations to the different levels of pollutants in the environment and may have varied contaminant concentrations in their living tissues, seeing that biochemical means of detoxification are active in the different species. Studies focusing on bioaccumulation in aquatic organisms specifically based on the substances' concentrations in tissues-organs, usually choose a target species in order to draw conclusions relating to the bioaccumulation and bioavailability of metals. A negative aspect of this kind of approach is the impact caused by the fishing method that affects not only the target species but also others, resulting in the discarding of by-catch species. Thus, the exploitation of a maximum number of species resulting from a single fishing effort is welcome in monitoring planning.

Beyond bioconcentration, aquatic pollution permits exposure of organisms to genotoxic agents resulting in DNA and chromosomal damage, identified in the cells of various fish tissues (e.g. liver, kidney, gills), normally in response to xenobiotics such as toxic metals, polycyclic aromatic hydrocarbons, polychlorinated biphenyls and other persistent priority organic pollutants (POP). ${ }^{9}$ The analyses of these types of damage using peripheral blood (erythrocyte) cells instead of tissues is highly useful, since peripheral blood cells are considered sensitive - as is the case of kidney cells, the main organ responsible for blood cell formation in fish, besides which they are easier to sample. ${ }^{10}$ Nuclear abnormalities in erythrocytes (NAEs), such as the presence of micronuclei (MNs), are recognized as important genotoxic biomarkers. ${ }^{11,12} \mathrm{MNs}$ are particularly responsible for the clastogenic and an eugenic compounds in the aquatic environment and can indicate latent risk to the biota Hoshina et al. ${ }^{1}$

The search for new bioindicator species in aquatic ecosystems is an arduous task since, due to the myriad of xenobiotics to which organisms are constantly exposed in coastal zones, these organisms must be capable of participating in the dynamics and responding to a great variety of environmental stressors such as trace metals and metalloids. Ideally, field expeditions should prioritize, wherever possible, the increase of sampling effort so as to use all the individuals in a given haul to minimize the impact on local fauna. This strategy is important in order to establish more sustainable conservation strategies, as well as to break the paradigm of ecotoxicology where the integrated knowledge of the abiotic environment, the dynamics of the contaminants and their responses in specific bioindicator species, is necessary. The knowledge of more indicator species should increase with the greater use of the multiple species found in a single catch.

The Ariidae catfish, Cathoropsspixii, has been validated as a bioindicator species for exposure to metals in natural aquatic ecosystems such as estuarine systems ${ }^{13,14}$ and the genotoxic effects in this fish submitted to different degrees of anthropogenic influence has been observed..$^{15}$ Taking into account the potential damage to environmental conditions, no target species were pre-defined in this present study, instead all the species caught, with the exception of Cathoropsspixii (catfish) - the focus of another study ${ }^{13,16}$ - were investigated.

Fish were sampled on the same field expedition performed in 2006, in order to collect the C. spixii specimens captured, being identified as associated fish species (accompanying fauna). These fish were collected also to determined trace metal concentrations in tissues and organs, biochemical and histopathological effects and genotoxic biomarkers. The intention is to give a broad picture of the contamination and genotoxic effects on other ichthyofaunal species, specially juveniles and fishes of commercial importance.

The main goals of this study are therefore: $i$ ) to provide data on metal concentrations in important members of the ichthyofauna, from the SSV and Cananéia estuaries, taking advantage of the accompanying fauna of the fishery effort of the bioindicator $C$. spixii; ii) to verify the bioaccumulation of trace metals and arsenic in different tissues (liver, gills and muscle), and iii) to observe the genotoxic effect on these fish by the analysis of the NAEs and micronuclei in order to suggest other candidates as bioindicators in estuarine ecosystems.

\section{Materials and methods}

\section{Study Area}

The biological samples were obtained during the execution of the project "Organic matter in environmental impact assessment in the marine environment: biochemistry, biogeochemistry, bioaccumulation and biotoxins" (MOBIO/FAPESP, process 2005/50769-2) at 14 and 13 sampling stations, respectively, in the SSV and Cananéia estuaries, in order to gauge the importance of the organic matter in these systems by the integrated study of water, sediment and organism parameters. The sampling was undertaken in summer 2006 in both the SSV and Cananéia estuaries, São Paulo (SP), Brazil (Figure 1). In SSV, fish were collected in two regions, namely, at site1-located in Santos Bay where the hydrodynamics and depurative process are more intense, and site2-in the inner area, close to the Cubatãoindustrial complex. In the Cananéia estuary, the organisms were sampled in three regions, namely, atsite1-in the inner area with intermediate marine and fluvial influence, and site2-in the northern region with major continental and fluvial influence; at site3-near the Trapandé bay, where oceanic influence and tidal in putare more accentuated.

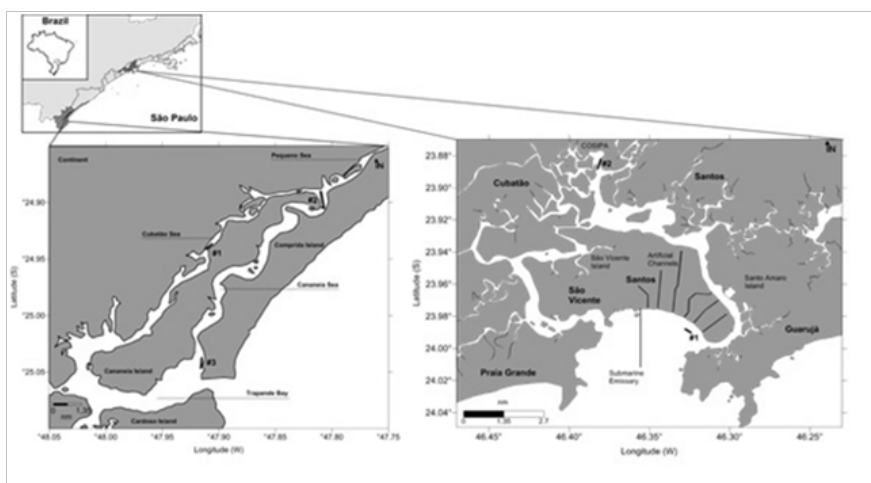

Figure I Sampling sites showing Santos-São Vicente and Cananeia estuaries, São Paulo State, Brazil.

\section{Acquisition of bottom water hydrophysicaldata}

Tidal data for the sampling period were obtained from the Laboratory of Tides and Ocean Processes (MAPTOLAB) of the Oceanographic Institute of São Paulo University (IOUSP) for the Cananeia estuary and from the Brazilian Navy for the SSV estuary. Local depth of the stations was obtained by the use of the echo sounders of the research vessels. Temperature was registered by a reversing thermometer coupled to hydrobios bottles (precision $\pm 0.02^{\circ} \mathrm{C}$ ). The salinity was determined using a BeckmanÒ RS-10 salinometer calibrated with standard seawater (precision \pm 0.001 ) and dissolved 
oxygen concentrations were determined by the Winkler method following the recommendations of Grasshoff et al. ${ }^{17}$

\section{Fish sampling and preparation of biological material}

The biological samples were obtained in order to increase the matrix of potential fish species for use as bioindicators of environmental pollution. Considering that the main initial efforts and the fishing strategy were focused on Cathoropsspixii in accord with previous studies, ${ }^{13,14}$ the associated fauna was dealt with, in the present research, in such a way as to optimize the capture and to increase the knowledge of the effects of pollution in the fish of both estuarine systems.

Fish were sampled using a bottom otter trawl net (1.6" mesh wall and 1.2 " mesh cod end) of $11 \mathrm{~m}$ length. Sampling was undertaken at an average depth of $6.6 \mathrm{~m}$ in the SSV estuary and at $5.5 \mathrm{~m}$ in the Cananeia estuary, subject, respectively, to considerable and slight pollution. The fish collected at each site were maintained in boxes in water from the respective sites, constantly aerated, and kept alive to withdraw blood samples, conserved with heparin; each individual being thereafter frozen. All the above process took place on board. In the laboratory, the frozen fish were prepared for identification in accordance with. ${ }^{18}$ The biometric information (total length and total weight) were registered and then the fish were conditioned in a freezer $\left(-4^{\circ} \mathrm{C}\right)$. Samples of fish muscle were obtained for three species etodipterusfaber, Paralanchurus brasiliensis and Micropogoniasfurnieri) of the SSV estuary ( $\mathrm{n}=$ 10) and for four species (Achiruslineatus, Genyatremusluteus, Menticirrhus Americanos and Micropogoniasfurnieri) of the Cananeia estuary $(\mathrm{n}=24)$.

For the calculation of bioaccumulation, liver and gills were also obtained for $C$. faber individuals $(\mathrm{n}=7)$. The tissue samples were freeze-dried by a process of lyophilization. Dried samples were transformed into powder, homogenized and conditioned for the metals analysis.

\section{Trace element determinations by INAA}

For the determination of trace elements, the multi elemental analysis by Instrumental Neutron Activation Analysis (INAA) was used. In this process, approximately $150 \mathrm{mg}$ of fish tissue (muscle, liver and gill) and reference materials (DOLT-1 and DORM-1) were accurately weighed and sealed in pre-cleaned polyethylene bags, for irradiation. Fish samples and reference materials were irradiated for 8 hours, under a thermal neutron flux of $1012 \mathrm{~cm}-2 \mathrm{~s}-1$ at the IEA-R1 nuclear research reactor of the Nuclear Research Institute (IPEN-São

Table I Hydrochemical parameter from the bottom water of different sites in the polluted estuary (Santos-São Vicente) and with low human influence (Cananeia)

\begin{tabular}{llllll}
\hline & Sites & \multicolumn{1}{l}{ Average Depth $(\mathbf{m})$ of Sampling $\mathbf{T}\left({ }^{\circ} \mathbf{C}\right)$} & Salinity & Dissolved Oxygen $\left(\mathbf{m L ~ L}^{-1}\right)$ \\
\hline Santos-S.Vicente & $\mathrm{I}$ & 8.8 & 25.91 & 33.17 & 4.59 \\
estuary & 2 & 6.5 & 25.76 & 27.75 & 1.95 \\
& $\mathrm{I}$ & 4.9 & 29.84 & 24.58 & 3.50 \\
Cananeia estuary & 2 & 4.9 & 27.10 & 9.80 & 3.97 \\
& 3 & 6.5 & 28.16 & 28.98 & 3.87 \\
\hline
\end{tabular}

The innermost region of the SSV and Cananeia estuaries presented the lower salinity values $\left(\right.$ st. $2_{\text {SSV }}=27.75$; st. $\left.2_{\text {Cananeia }}=9.80\right)$. Specifically for the Cananeia estuary, st.3 showed the lower salinity, thus indicating the more intense fluvial influence in the northern area of the estuary. Dissolved oxygen (DO) concentrations below $3.00 \mathrm{~mL}$ $\mathrm{L}^{-1}$ were obtained in the inner area of the SSV $\left(\mathrm{st}_{2}{ }_{\mathrm{DO}}=1.95 \mathrm{mLL}^{-1}\right)$, but values above $4 \mathrm{~mL} \mathrm{~L}^{-1}$ were observed in the region under greater marine influence $\left(\right.$ st. $\left.1_{\mathrm{DO}}=4.59 \mathrm{mLL}^{-1}\right)$. On the other hand, DO levels
Paulo- Brazil). The elements investigated by INAA were As, Co, Cr, $\mathrm{Fe}, \mathrm{Se}, \mathrm{Zn}$ and $\mathrm{Hg}$. The precision and accuracy of the methods were verified by measuring the reference materials DOLT-1 (Dogfish Liver Certified Reference Material for Trace Metals, NRCC) and DORM1 (Dogfish Muscle Certified Reference Material for Trace Metals, NRCC).

\section{Nuclear abnormalities in erythrocytes (NAEs)}

Fish blood samples were taken from the caudal artery with heparinized syringes and needles. A drop of fish blood was smeared on a microscope slide and air-dried. After fixation with methanol for 10 minutes, slides were stained with Giemsa $10 \%$ for 30 minutes. The counting of NAEs on the microscope slides was performed under microscopy-immersion light. The slides were observed with an optical magnification of 1000 times, scoring an average of 1000 mature mononucleated erythrocytes as described by Carrasco et al. ${ }^{19}$

Due to problems in the preparation of the slides, since this procedure was under taken on board the research vessels, some of them had poor resolution and were discarded. Only those that presented good quality for erythrocyte observation were used and the anomalies registered. Thus not all the samples were examined.

\section{Data presentation}

Metals content and nuclear abnormalities in erythrocytes (NAE) and micronuclei $(\mathrm{MN})$ in fish of both the estuaries were shown by using a Box Plot as a quartile method of rounding with whisker length, one sigma and standard deviation with the use of Past 3.0 software. Environmental water data, the biometry limit values and individual values are presented in table form (?) to contribute to knowledge of all the species caught.

\section{Results}

\section{Hydrophysicaldata}

The sampling at the two sites in the Santos/São Vicente estuary was do neat ebb tide and under syzygy conditions. On the other hand, in the Cananeia estuary, the sampling was do neat flood tide at sites 2 and 3 and atebb tide in the innermost sector of the estuary (st. 1), all in quadrature.

In order to understand the aquatic environmental of the sites sampled, some hydrological parameters were obtained at each fish sampling site. Temperature, salinity and dissolved oxygen data of the bottom water are given in table1. 
and some of them benthic (Table. 2). This means that they are all closely related to the seafloor, feeding on the sediment or close to it, and potentially exposed to the contaminants deposited there.

The biometric data of the fish are shown in table 2. Regarding the fish from the SSV estuary, the total length and weight of $C$. faber ranged from 169 to $246 \mathrm{~mm}$ and 152.32 to $479.47 \mathrm{~g}$, respectively; four of the seven individuals were female and three male. $P$. Brasiliensis presented a total length, considering the two specimens collected, of 200 and $201 \mathrm{~mm}$, and weighing 71.14 and $79.94 \mathrm{~g}$, one male being identified and the other not. Concerning $M$. furnieri, only one individual was collected with total length and weight of $234 \mathrm{~mm}$ and $137.13 \mathrm{~g}$, respectively, of unidentified sex.

In relation to the fish from the Cananeia estuary, the total length of the flatfish - A. lineatus - ranged from 92 to $113 \mathrm{~mm}$, and their weight varied from 17.69 to $27.5 \mathrm{~g}$; two of them were female and one was of unidentified sex. Three females and three males of $G$. Luteus were collected with total length ranging from 149 to $171 \mathrm{~mm}$ and total weight varying from 54.85 to $88.42 \mathrm{~g}$. The total length and weight of M. americanos ranged from 126 to $160 \mathrm{~mm}$ and 19.68 to $38.55 \mathrm{~g}$, respectively; all the specimens collected were females. $M$. furnieri had total length ranging from 94 to $160 \mathrm{~mm}$, and weight from 6.68 to $40.84 \mathrm{~g}$, six were male and three were not identified.

\section{Trace elements in fish muscle}

The trace metals in fish muscle were analyzed separately in the light of their being essential, i.e. having a definite biological function or otherwise. For the essential metals (Co, Fe, Se and $\mathrm{Zn}$ ), higher concentrations were observed in the fish species collected in Cananeia than in SSV (Figure 2).

Cobalt concentrations were clearly higher in fish from the Cananeia estuary with mean values ranging from 0.05 to $0.09 \mathrm{mgkg}^{-1}$. On the other hand, species from the SSV estuary had mean values ranging from 0.02 to $0.03 \mathrm{mgkg}^{-1}$. Differences in Co levels among species were observed only in Cananeia, and M. americanus presented higher levels $\left(0.90 \mathrm{mgkg}^{-1}\right)$ than the other species $(0.48$ to $0.61 \mathrm{mg}$. $\left.\mathrm{kg}^{-1}\right)$. The iron content in fish from the Cananeia estuary presented some outliers that might reflect individual variation of the specimens (Table 1). Mean values in the species varied from 15 to $35 \mathrm{mgkg}$ 1, while in species from SSV estuary no Fe levels were detected $(<\mathrm{DL})$ in some species - C. faber for instance. The mean Fe values in the species varied from 10 to $21 \mathrm{mgkg}^{-1}$, which might indicate a Fe deficiency in the fish of the Santos-São Vicente estuary sampled. No differences were observed in Fe levels as between species. Selenium concentrations were also higher in fish from the Cananeia estuary, the mean values in the species varied from 1.50 to $3.20 \mathrm{mgkg}^{-1}$. Species from the SSV estuary varied from 1.50 to $2.17 \mathrm{mgkg}^{-1}$. Differences in Se levels among species were observed only in Cananeia, where $M$. americanus and A. lineatus presented slightly higher values than the others. Zinc concentrations were also higher in fish from Cananeia estuary, with mean values in the species varying from 18 to $32 \mathrm{mgkg}^{-1}$, whereas in fish from the SSV estuary, the mean values in the species varied from 14 to $19 \mathrm{mgkg}^{-1}$.

Table 2 Biometric variables such as total length (TL) and total weight (TW) measured in different species from SSV and Cananeia estuaries. Data as showed as mean \pm standard deviation. $n=$ sample size

\begin{tabular}{|c|c|c|c|c|c|}
\hline & Spp. & Habitat & $n$ & TL (mm) & TW (g) \\
\hline \multirow{3}{*}{ SSVestuary } & C. faber & $\begin{array}{l}\text { Reef-associated; } \\
\text { benthic feed habit (invertebrates like crustaceans, } \\
\text { mollusks, annelids or cnidarians)a }\end{array}$ & 7 & $188.57 \pm 26.39$ & $233.04 \pm 112.47$ \\
\hline & P.brasiliensis & $\begin{array}{l}\text { Demersal; } \\
\text { benthic feeding habit ( } \\
\text { i.e. mainly on worms)b }\end{array}$ & 2 & $200.50 \pm 0.70$ & $75.54 \pm 6.22$ \\
\hline & M. furnieri & $\begin{array}{l}\text { Demersal; } \\
\text { Juveniles feed on benthic migratory crustaceans and } \\
\text { sessile boring mollusks while adults are benthos-feeders } \\
\text { and occasionally capture fishb. }\end{array}$ & 1 & $234.00^{*}$ & $137.13^{*}$ \\
\hline \multirow{4}{*}{ Cananeia estuary } & A. lineatus & $\begin{array}{l}\text { Reef-associated; benthic feed habit (i.e. worms, } \\
\text { crustaceans and small fishes)c }\end{array}$ & 3 & $104.00 \pm 8.18$ & $21.64 \pm 5.18$ \\
\hline & G. luteus & Demersal; Feeds on crustaceansd. & 6 & $158.83 \pm 9.95$ & $71.54 \pm 14.60$ \\
\hline & M.americanos & Demersal; benthic feed habit b & 6 & $|44.17 \pm| \mid .46$ & $29.89 \pm 6.55$ \\
\hline & M. furnieri & $\begin{array}{l}\text { Demersal. } \\
\text { Juveniles feed on benthic migratory crustaceans and } \\
\text { sessile boring mollusks while adults are benthos-feeders } \\
\text { and occasionally capture fish b. }\end{array}$ & 9 & $133.11 \pm 19.07$ & $24.08 \pm 10.40$ \\
\hline
\end{tabular}

Regarding trace elements, such as As and $\mathrm{Hg}$, with no positive biological function, no specific pattern could be observed. Arsenic concentrations in fish from Cananeia estuary showed mean values in the species varying from 1.8 to $5.6 \mathrm{mgkg}^{-1}$, and fish from SSV estuary showed mean values from 2.5 to $4.5 \mathrm{mgkg}^{-1}$ (Figure 3 ). Specifically regarding $\mathrm{Hg}$ content, it was possible to observe an inverse pattern from that obtained for trace metals with a definite biological function, with higher concentrations in species collected in the SSV estuary (mean values in species varying from 0.13 to $0.23 \mathrm{mgkg}^{-1}$ ) and in individuals from Cananeia estuary, the greater part of the species had no detectable $\mathrm{Hg}$ concentrations (Figure 3).

\section{Nuclear Abnormalities in Erythrocytes (NAEs)}

The more frequent nuclear alterations in the erythrocytes of the fishes sampled are shown in figure 4 . The species collected in the Santos-São Vicente estuary showed a greater frequency of NAEs (19 to 29\%o) than the species from the Cananeia estuary (6 to 10\%o). In fact, no fish from the estuary with low pollution presented any occurrence of micronuclei (Figure 5). On the other hand, different species from the SSV estuary showed a mean MN occurrence varying from 1 to $2 \%$. 

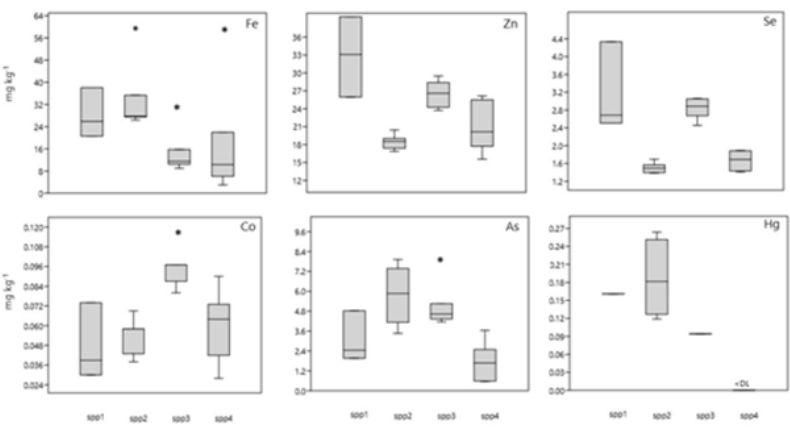

Figure 2 Box plots of essential and non-essential trace metals in muscle of fish from Cananeia estuary. (*) are the outliers, the values in the middle of the boxes are the medians, and the dots $(\bullet)$ represent each individual concentration. Spp I - A. lineatus; Spp2 - G. luteus; Spp3 - M. americanos; Spp4 - M. furnieri.
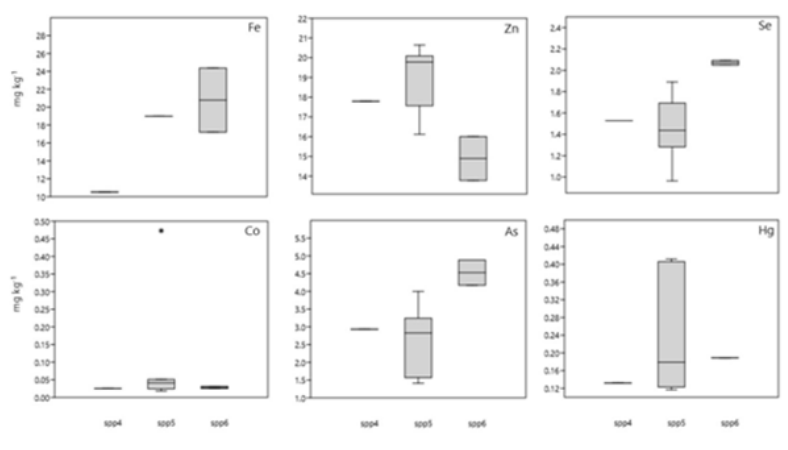

Figure 3 Box plots of essential and non-essential trace metals in muscle of fish from Santos/São Vicente estuary. $\left(^{*}\right)$ are the outliers, the values in the middle of the boxes are the medians, and the dots $(\bullet)$ represent each individual concentration. Spp4 - M. furnieri; Spp5 - C. faber; Spp6 - P. brasiliensis.
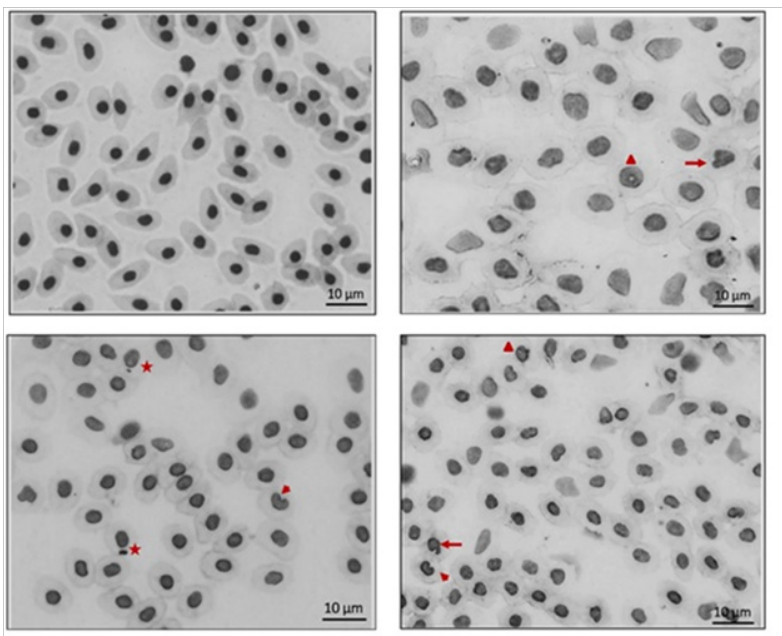

Figure 4 Fish erythrocytes indicating: (A) Normal; $(\Delta)$ Vacuolizated. $(\rightarrow)$ Lobed; ( ) Notched; (*)Micronuclei.

\section{Bioaccumulation inferences in C.faber from the SSV estuary}

Data on essential and non-essential metals in the gills, liver and muscle of $C$. faber are presented in figure 6.Cobaltlevels in muscle ranged from 0.018 to $0.053 \mathrm{mg} \mathrm{kg}^{-1}$ with an outlier in one of the samples that presented $0.47 \mathrm{mg} \mathrm{kg}^{-1}$. In liver, the Co levels ranged from 0.19 to $0.50 \mathrm{mg} \mathrm{kg}^{-1}$ and in gills from 0.18 to $0.48 \mathrm{mg} \mathrm{kg}^{-1}$. Iron $(\mathrm{Fe})$ levels ranged from 10 to $19 \mathrm{mg} \mathrm{kg}^{-1}$ in muscle, 338 to $2,142 \mathrm{mg}$ $\mathrm{kg}^{-1}$ in liver and 423 to $1,084 \mathrm{mg} \mathrm{kg}^{-1}$ in the gills, as observed in SSV.
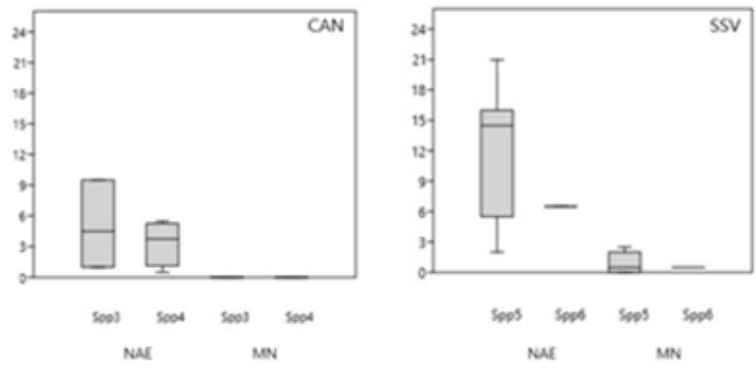

Figure 5 Box plots of frequency of erythrocyte nuclear anomalies, in fish from Santos/São Vicente and Cananeia estuaries, (*) represents the outliers, the values in the middle of the boxes are the medians, and the dots $(\bullet)$ represent each individual value. CA - Cananéia estuaryand SSV - Santos/São Vicente Estuary; CA - Cananéia estuaryand SSV - Santos/São Vicente Estuary. Spp3 - M. americanos; Spp4 - M. furnieri; Spp5 - C. faber; Spp6 - P. brasiliensis.
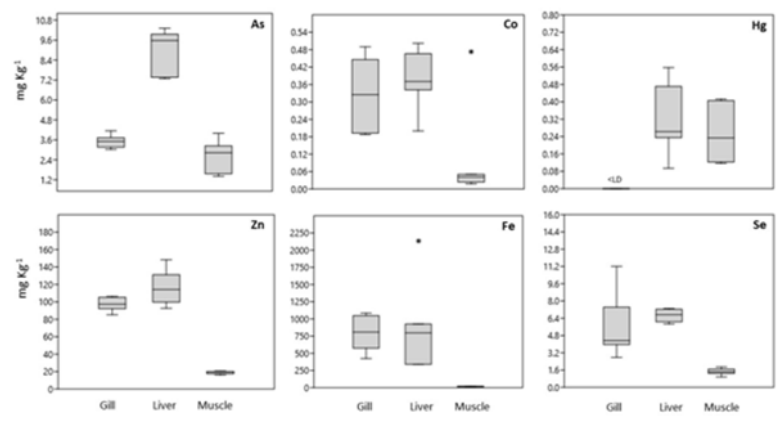

Figure 6 Boxplot of trace metals in C. faber tissues from SSV, (*) represents the outliers, the values in the middle of the boxes are the medians, and the dots $(\bullet)$ represent each individual concentration.

Selenium concentration in muscle presented limits from 0.96 to $1.89 \mathrm{mg} \mathrm{kg}^{-1}$, in liver from 5.86 to $7.31 \mathrm{mg} \mathrm{kg}^{-1}$, and in gills from 2.77 to $11.20 \mathrm{mg} \mathrm{kg}^{-1}$. Zinc (Zn) in muscle varied from 16.12 to $20.64 \mathrm{mg}$ $\mathrm{kg}^{-1}$, in liver from 92.70 to $148.24 \mathrm{mg} \mathrm{kg}^{-1}$, and in gills from 85.18 to $106.29 \mathrm{mg} \mathrm{kg}^{-1}$.

Regarding non-essential semi-metals, As levels in muscle ranged from 1.41 to $3.99 \mathrm{mg} \mathrm{kg}^{-1}$, in liver from 7.28 to $10.31 \mathrm{mg} \mathrm{kg}^{-1}$, and in gills from 3.02 to $4.12 \mathrm{mg} \mathrm{kg}^{-1}$. Total mercury $(\mathrm{THg})$ was not detected in gills but presented levels varying from 0.11 to $0.41 \mathrm{mg} \mathrm{kg}^{-1}$ in muscle and from 0.09 to $0.55 \mathrm{mg} \mathrm{kg}^{-1}$ in liver. No $\mathrm{Cr}$ was detected in liver. In muscle, it was only detected in three samples with greatly differing levels, presenting the following values: 175.66; $630 \mu \mathrm{g}$ $\mathrm{kg}^{-1}$ and an outlier of $72359,51 \mu \mathrm{g} \mathrm{kg}^{-1}$. Cr was detected in the gills in all samples, ranging from 0.64 to $1.67 \mu \mathrm{g} \mathrm{kg}^{-1}$.

Considering metals with essential ( $\mathrm{Co}, \mathrm{Fe}, \mathrm{Se}, \mathrm{Zn})$ and nonessential (As and $\mathrm{Hg}$ ) roles, it was noted that all average metal levels, with the exception of $\mathrm{Hg}$ and $\mathrm{Cr}$, had lower values in muscle, followed by gills and liver, which presented the highest concentrations. However, some of the essential metals showed much higher levels overall in the gills and liver than in muscle in relation to $\mathrm{Co}, \mathrm{Fe}$ though less so regarding $\mathrm{Zn}$. The non-essential metals exhibited no pattern of sequential concentration in organs and tissues, in general, however, no $\mathrm{Hg}$ was detected in gills but presented very similar levels in muscle 
and liver. On the other hand, no chrome was detected in liver, though it was detected in all gill samples and presented higher concentrations in two muscle samples.

\section{Discussion}

Fish are recognized as passive agents regarding their revelation of environmental changes as all abiotic and/or organic and inorganic inputs and alterations in the environment directly affect their metabolism. The characterization of aquatic systems is therefore very important, especially if it is possible thus to accompany responses in systems subject to different levels of human occupation by reason of the responses of some species with complementary ecological habits. The Cananeia and SSV estuaries are subject to different degrees of anthropogenic impact. A study conducted by Azevedo and Braga ${ }^{16}$ has presented the differences regarding some chemical and physical parameters, such as dissolved oxygen (DO), $\mathrm{pH}$, organic matter (OM), suspended particulate matter (SPM), and the levels of some essential nutrients such as nitrogen and phosphate. The authors cited presented results for the summer of 2006 in order to give some indication of the hydrochemical and physical conditions in those areas. The $\mathrm{pH}$ in the SSV estuary was 7.8 in the inner region (nearst. 2) and more than 8.0 in Santos Bay (nearst. 1). In the Cananeia estuary, the same authors showed a $\mathrm{pH}$ above 8 at all the stations. Regarding dissolved oxygen, in the SSV estuary, they presented values of $2.0 \mathrm{mgL}^{-1}$ and $3.5 \mathrm{mgL}$ ${ }^{1}$, respectively, in the inner area of the estuary (nearst. 2) and in the channel (near st. 1).Considering the two systems, in the Cananeia estuary, the dissolved oxygen levels were higher than $3 \mathrm{mgL}^{-1}$ at all the stations and the nutrient levels, of, for instance, nitrite, nitrate and phosphate were higher in the inner area of the SSV estuary, reflecting the impact of anthropogenic activities, e.g. the industrial activitymainly of Cubatão city (an industrial pole). These data indicate the existence of better environmental conditions in the Cananeia estuary than in the SSV estuary and the low levels of dissolved oxygen in SSV and the low $\mathrm{pH}$ suggest a hypoxic area. However, this was observed exclusively in the inner area of the SSV estuary, the conditions in the Santos channel (st. 1) due to oceanic influence being close to those observed in the Cananeia estuary with regard to these parameters Azevedo and Braga. ${ }^{16}$

The hydrophysical data on dissolved oxygen (DO) obtained in the present study are in accordance with those obtained by Azevedo and Braga. ${ }^{16}$ The lower levels of DO observed in the inner area of the SSV estuary may reflect hypoxic conditions and therefore affect the responses in bioindicator fish. In this study, it was, further, possible to observe a differential pattern in the salinity of the two estuaries. This profile is a consequence of the greater fluvial input in the inner region of the estuaries. On the other hand, the higher salinity in the more external area is due to the more intense marine hydrodynamic, mainly in flood syzygy tides, when the tidal amplitude and marine water inflow is greater in the estuarine system. Unfortunately, the conditions due to greater anthropogenic influence in the SSV has been maintained over time.

In general, the toxicity of metals is high under conditions of low salinity and high temperature, which generally favor the rate of accumulation in environments such as estuaries. In this study, the results of trace elements (considering essential metals) obtained in muscle tissues were higher in fish species from the Cananeia estuary than in specimens from the SSV estuary. On the other hand, the levels for Hg were higher in individuals from the SSV estuary. These results are in accordance with the data on metals obtained for the bioindicator species Cathoropsspixii from both these estuaries, in similar sampling areas. ${ }^{14}$
The metal contents determined in this study have been compared to the levels of the same metals obtained for other fish with similar feeding habits around the word (Table 3 ). $\mathrm{Hg}$ levels are in accordance with the results obtained in other fish with similar feeding habits. However, it was possible to observe an accumulation of the other metals in relation to feeding habits. For $\mathrm{Cr}, \mathrm{Fe}$ and As, the major concentrations were observed in fish with pelagic or neritic habits, which might suggest a differential metabolism for these metals in fish. The lower levels of As observed in fish of benthic or demersal habits might be related to the organic transformation of this semimetal since marine organisms contain As in the organic form of arsenobetaine, a non-toxic compound with the biological function of reducing environmental stress due to high salinities..$^{20}$ The absence of differences in the Se and $\mathrm{Zn}$ concentrations in fish of pelagic/neritic or benthic/demersal feeding habits might be a consequence of the detoxification processes of these metals since Se has the important function of regulating the $\mathrm{Hg}$ balance in organisms in order to decrease its toxicity. Then, $\mathrm{Zn}$ is a micronutrient present in several metallo proteins and can act in $\mathrm{Cu}$ regulation. So the presence of a relative concentration of essential metals in the organism is part of the normal metabolism which constructs important bio-macromolecules, and in the case of As a differential role in the osmotic regulation takes place by virtue of the salinity, which puts this element into another kind of toxicity classification in marine organisms.

Concerning $C$. faber, it was observed that in the bioaccumulation processes of some metals such as $\mathrm{Co}, \mathrm{Se}, \mathrm{Zn}, \mathrm{Hg}, \mathrm{Fe}$ and the metalloid As, the standard profiles of increase in bioconcentration at higher levels of exposition were found in the liver, the most important detoxification organ in fish. However, differences with respect to metal concentrations in gills and muscle tissue showed, respectively, distinct acute and chronic exposure.

In studies with some fish such as the Atlantic killifish Fundulusheteroclitus, the Poecilia vivipara and the euryhaline fish Galaxias macalatus, it has been possible to observe metal accumulation; for instance $\mathrm{Zn}, \mathrm{Cu}$ and $\mathrm{Ni}$ were considered tissue-specific and salinity dependent. ${ }^{21-23} \mathrm{In}$ relation to $\mathrm{Zn}$ specifically, it has been observed that $\mathrm{Zn}$ exposure changes $\mathrm{Ca}^{+2}$ and $\mathrm{Na}^{+}$homeostasis negatively, but an increase in salinity has a protective effect against lethal $\mathrm{Zn}$ toxicity ${ }^{21,24}$ consider that high levels of $\mathrm{Ca}$ and $\mathrm{Mg}$ can increase competition with $\mathrm{Ni}$ for access to the divalent cation absorption pathways, in order to mediate its uptake into aquatic biota. This statement could contribute to the understanding of the observed metal levels in the gills of $C$. faber. Furthermore, the hydrochemical achieves, such as that of salinity, are of great importance not only in the understanding of the toxicity of metals, but also in that of the bioaccumulation processes in marine organisms, those which present a different osmotic process from that of freshwater fish. In transitional environments such as estuaries, studies of these mechanisms are to be encouraged.

The concentrations of $\mathrm{Co}, \mathrm{Zn}, \mathrm{Se}$ and $\mathrm{Fe}$ in gills may be an indication of an input from the environment by means of changes and the adsorption process in the branchial lamellas, differently from what occurs in muscle concentrations. The bioaccumulation results in $C$. faber obtained in this study for some metals such as $\mathrm{Co}, \mathrm{Se}, \mathrm{Zn}, \mathrm{Hg}, \mathrm{Fe}$ and the semi-metal As are in accordance with the responses of the profile of bioaccumulation observed in the catfish Cathoropsspixii and Genidensgenidens from the SSV and Cananeia estuaries. ${ }^{25}$

In order to understand the biological damage caused by mutagenic agents in polluted water, the use of nuclear abnormalities in 
erythrocytes (NAE), for instance by micronuclei testing, has been employed. NAE are sensitive non-specific indicators of mutagenic damage, they can however provide an additional tool for the understanding of the genotoxic effect and have been used by some authors in biomonitoring studies. ${ }^{15,26,27}$ In the four species analyzed (M. americanus, M. furnieri, C. faber and P. brasiliensis) in relation to the expression of genotoxic effects, $C$. faber was the most responsive since it showed a more significant NAE, as well as clastogenic effects expressed with a greater frequency of micronuclei. In general, fish from environments subject to weak human influence have a NAE frequency range of $3-20 \% .{ }^{28,27}$ Arslan et al. ${ }^{26}$ observed a higher MN frequency in five fish species from water polluted by domestic and industrial sewage than in fish from relatively clean water in Aliaga Bay (Turkey) with a MN frequency ranging from $15-40 \%$. A similar profile was observed in this study though the differences could have been due to the feeding habit of the species. Thus the data obtained in this study are in accordance with those of others undertaken in natural environments subject to anthropogenic influence around the world.

Table 3 Metal concentrations $\left(\mathrm{mg} . \mathrm{Kg}^{-1}\right)$ for some coastal and marine fish. Cr levels in gills are given in $\mu \mathrm{g} . \mathrm{kg}^{-1}$

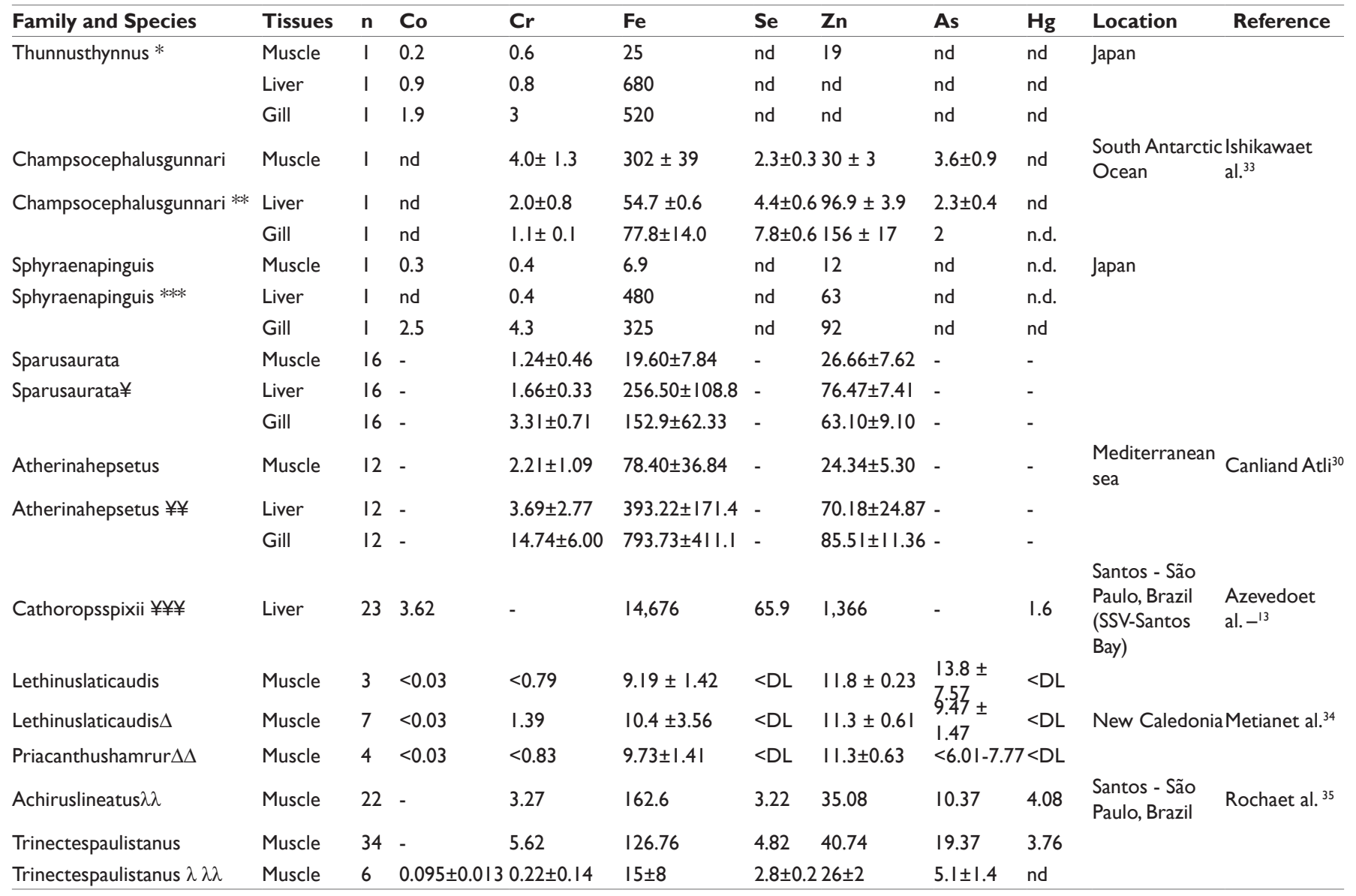

Data shown as mean values or mean \pm standard deviation. $n=$ sample size; $\mathrm{nd}=$ not detected; $\mathrm{DL}=$ detection limit. $\mathrm{Nd}=$ not detected; $-=$ without information.

* Riede (2004) Pelagic-oceanic. Feed on small schooling fishes.

**Miller (1993) Pelagic-oceanic. Feed mainly on krill and mysids.

***KuiterandTonozuka (200I) Pelagic-neritic. Feeds on fishes.

¥ Muusand Nielsen (1999) Demersal. Feed on shellfish, including mussels and oysters.

$¥ ¥$ Quignardand Pras (1986) Pelagic-neritic. Feed on pelagic copepods and benthic crustaceans.

¥¥ Figueiredo and Menezes(1978) Demersal. Feed mainly on invertebrates and small fishes.

$\Delta$ Allen andErdmann (2012) Neritic Reef associated. Feeds mainly on crustaceans and fishes.

$\Delta \Delta$ Fischer et al. (1990) Neritic Reef associated. Feeds on small fish, crustaceans, and other small invertebrates.

$\theta \theta$ Cervigón et al. (1992) Demersal. Feeds on fish and crustaceans.

$\theta \theta \theta$ Planquette et al. (1996) Pelagic-neritic. Feeds on crustacean larvae or small invertebrates.

$\lambda \lambda$ MenenzesandFigueiredo (2000) Benthic. Reef-associated. Feed on worms, crustaceans and small fishes.

In fact, the bioaccumulation data of trace elements in association with the genotoxic responses presented by C. Faber from the SSV estuary, allows us to encourage the focus on this species for use as a bioindicator of metals and metalloid exposures in estuarine and marine environments. However, in order to reinforce this suggestion, it is very important to continue to feed the databank with more information from the SSV estuary and from estuaries subject to low human impact to confirm this characteristic of this species, beyond which it is important to increase information regarding others actors for use as bioindicators of trace metal pollutants, thus making fish sampling 
efforts more productive in terms of the advance of knowledge on the situation of the food chain and the increase in the number of potential bioindicator species. ${ }^{27-35}$

\section{Conclusion}

This study allows the authors to confirm the importance of investing in the fishery sampling effort with a view to increasing the number of species available for the matrix for observing the contaminating effects in aquatic systems resulting from bioaccumulation and genotoxicity and also to increasing knowledge of the role of the trophic structure in environmental monitoring. The paradoxical increase of trace elements in fish from the most pristine region justifies studies of the association between fish species and the associated environmental conditions of each group, possibly associated with the salinity conditions that lead to specific metabolic reactions possibly involved in the ionic change seeking isostatic balance that could be associated with the bioconcentration of unsuitable elements. This study also resulted in a proposal for another monitoring species for estuarine systems: C. faber which presented special characteristics as regards the accumulation of trace elements such as $\mathrm{Hg}$, As, Co, Se and $\mathrm{Zn}$ in tissues-organs in this order: liver, gills and muscle.

\section{Acknowledgments}

The authors would like to thank the São Paulo Foundation for Research Support -FAPESP for the grant to the project MOBIO (Process 2005/50769-2) - and the Institute of Energy and Nuclear Research for supporting this research. We would also thank the crews of the Velliger and Albacora research vessels.

\section{Conflicts of Interest}

The authors declares that they has no conflict of interest. All applicable international, national, and/or institutional guidelines for the care and use of animals were followed.

\section{References}

1. Day JH. What is a estuary. South African JSci. 1980;76:198.

2. Millennium Ecosystem Assessment. Ecosystems and human wellbeing: wetlands and water synthesis. Washington, DC: World Resources Institute USA. 2005;pp.1-80.

3. Kennish MJ. Ecology of estuaries: anthropogenic effects. London: CRC Press. 1991

4. Machado AA de S, Spencer K, Kloas W, et al. Metal fate and effects in estuaries: A review and conceptual model for better understanding of toxicity. Sci Total Environ. 2015;541:268-281.

5. Bai J, Zhao Q, Lu Q, et al. Effects of freshwater input on trace element pollution in salt marsh soils of a typical coastal estuary, China. J Hydrol. 2015;520:186-192.

6. Wood CM, Farrell AP, Brauner CJ. Homeostasis and toxicology of essential metals. Elsevier. 2011;v.31.

7. United Nations Educational, Scientific and Cultural Organization (UNESCO). World Network of Biosphere Reserves - SC/EES - Jumne. The MAB Program. 2005;pp.19.

8. Livingstone DR. The fate of organic xenobiotics in aquatic ecosystems: Quantitative and qualitative differences in biotransformation by invertebrates and fish. Comp Biochem Physiol: Molecular Integrative Physiol. 1998;120(1):43-49.

9. Obiakor MO, Okonkwo JC, Ezeonyejiaku CD. Genotoxicity of freshwater ecosystem shows DNA damage in preponderant fish as validated by in vivo micronucleus induction in gill and kidney erythrocytes. Mutation Research: Genetic Toxicol Environ Mut. 2014;775:20-30.

10. Gutiérrez JM, Villar S, Acuña AP. Micronucleus test in fishes as indicators of environmental quality in subestuaries of the Río de la Plata (Uruguay). Mar Pollut Bull. 2015;91(2):518-523.

11. Guilherme S, Válerga M, Pereira ME, et al. Erythrocytic nuclear abnormalities in wild and caged fish (Liza aurata) along an environmental mercury contamination gradient. Ecotoxicol Environ Safety. 2008;70(3):411-421.

12. Marques SM, Antunes SC, Pissarra H, et al. Histopathological changes and erythrocytic nuclear abnormalities in Iberian green frogs (Rana perezi Seoane ) from a uranium mine pond. Aquatic Toxicol. 2009;91(2):187-195.

13. Azevedo JS, Fernandez WS, Farias LA, et al. Use of Cathorops spixii as bioindicator of pollution of trace metals in the Santos Bay, Brazil. Ecotoxicol. 2009;18(5):577-586.

14. Azevedo JS, Sarkis JES, Hortellani MA, et al. Are Catfish (Ariidae) Effective Bioindicators for $\mathrm{Pb}, \mathrm{Cd}, \mathrm{Hg}, \mathrm{Cu}$ and $\mathrm{Zn}$ ? Water Air Soil Pollut. 2012a;223(7):3911-3922.

15. Azevedo JS, Braga ES, Oliveira Ribeiro CA. Nuclear Abnormalities in erythrocytes and morphometric indexes in the catfish Cathorops spixii (Ariidae) from different sites on the southeastern Brazilian coast. Braz $J$ Ocean. 2012b;60(3):323-330.

16. Azevedo JS, Braga ES. Caracterização hidroquímica para qualificação ambiental dos estuários de Santos-São Vicente e Cananéia. Arquivos Ciên Mar. 2011;44(2):52-61.

17. Grasshoff K, Ehrhardt M, Kremling K. methods of seawater analysis (2nd edn), Verlag Chimie. 1983;419p.

18. Menezes NA, Figueiredo JL. Manual de peixes marinhos do sudeste do brasil. v.teleostei (4). São Paulo: Museu de Zoologia, Universidade de São Paulo. 1985

19. Carrasco KR, Tilbury KL, Myers MS. Assessment of the Piscine Micronucleus Test as an in situ Biological indicator of Chemical Contaminant Effects. Canadian J Fish Aquatic Sci. 1990;47(11):21232136 .

20. Peshut PJ, Morrison RJ, Brooks BA. Arsenic speciation in marine fish and shellfish from American Samoa. Chemosphere. 2008;71(3):484 492.

21. Loro VL, Nogueira L, Nadella SR, et al. Zinc bioaccumulation and ion regulatory impacts in Fundulus heteroclitus exposed to sublethal water bone zinc at different salinities. Comp Biochem Physiol, Part C. 2014;166:96-104.

22. Sampaio da Silva E, Abril SIM, Zanette J, et al. Salinity dependent copper accumulation in the guppy Poecilia vivipara is associated with CTR1 and ATP7B transcriptional regulation. Aquatic Toxicol. 2014;152:300-307.

23. Blewett TA, Wood CM, Glover CN. Salinity-dependent nickel accumulation and effects on respiration, ion regulation and oxidative stress in the galaxiid fish, Galaxias maculatus. Environ Pollut. 2016;214:132-141.

24. Blewett TA, Ramsberry VE, McClelland GB, et al. Investigating the mechanisms of Ni uptake and sub-lethal toxicity in the Atlantic killifish Fundulus heteroclitus in relation to salinity. Environ Pollut. 2016a ;21:370-381.

25. Azevedo JS, Hortellani MA, Sarkis JES. Accumulation and distribution of metals in the tissues of two catfish species from Cananéia and SantosSão Vicente estuaries. Braz J Ocean. 2012c ;60(4):463-472. 
26. Arslan OÇ, Boyacioglu M, Parlak H, et al. Assessment of micronuclei induction in peripheral blood and gill cells of some fish species from Aliaga Bay Turkey. Mar Pollut Bull. 2015;94(1-2):48-54.

27. Capela R, Raimundo J, Santos MM, et al. The use of biomarkers as integrative tools for transitional water bodies monitoring in the water framework direct context - A holistic approach in Minho river transitional waters. Sci Total Environ. 2016;539:85-96.

28. Santos MM, Solé M, Lina D, et al. Validating a multi-biomarker approach with the shanny Lipophrys pholis to monitor oil spills in European Marine Ecossystem. Chemosphere. 2010;81(6):685-691.

29. Avigliano E, Schenone NF, Volpedo AV, et al. Heavy metals and trace elements in muscle of silverside (Odontesthes bonariensis) and water from different environments (Argentina ): aquatic pollution and consumption effect approach. Sci Total Environ. 2015;506:102-108.

30. Canli M, Atli G. The relationships between heavy metal $(\mathrm{Cd}, \mathrm{Cr}, \mathrm{Cu}$ , Fe , Pb , Zn) levels and the size of six Mediterranean fish species. Environ Pollut. 2003121(1):129-136.
31. Figueiredo JL, Menezes NA. Manual de peixes marinhos do sudeste do Brasil. iii. teleostei (2). São Paulo: Museu de Zoologia, Universidade de São Paulo. 1980.

32. Figueiredo JL, Menezes NA. Manual de peixes marinhos do sudeste do Brasil. vi.teleostei (5). São Paulo: Museu de Zoologia, Universidade de São Paulo. 2000.

33. Ishikawa M, Nakamura K, Ishii T, et al. Elements in tissues and organs of an Antarctic fish, Charnpsocephalus gunnari. Nuclear Instruments Methods Physics Research Section B: Beam Interactions with Materials and Atoms. 1993;75(1-4):204-208.

34. Metian M, Warnau M, Chouvelon T, et al. Trace element bioaccumulation in reef fish from New Caledonia: Influence of trophic groups and risk assessment for consumers. Mar Environ Res. 2013;87:26-36.

35. Rocha MLF, Dias JF, Boufleur LA, et al. Metal concentration in muscle of two species of flatfish from Santos Bay, Southeastern Brazilian coast. Nuclear Instruments Methods Physics Research, Section B: Beam Interactions Materials Atoms. 2014;318:88-93. 